British Journal of Medicine \& Medical Research

7(7): 580-584, 2015, Article no.BJMMR.2015.364

ISSN: 2231-0614

SCIENCEDOMAIN international

www.sciencedomain.org

\title{
The Male: Female Ratio at Birth in Malta is Decreased by the Soccer World Cup
}

\author{
Grech Victor $^{1^{*}}$ \\ ${ }^{1}$ Department of Paediatrics, University of Malta, Mater Dei Hospital, Malta.
}

Author's contribution

The sole author designed, analyzed and interpreted and prepared the manuscript.

Article Information

DOI: 10.9734/BJMMR/2015/16289

Editor(s):

(1) Oswin Grollmuss, Department of Pediatric and Adult Resuscitation Congenital Heart of Centre Chirurgical Marie Lannelongue, University Paris XI, France.

Reviewers:

(1) Georgios Androutsopoulos, Department of Obstetrics Gynecology, School of Medicine, University of Patras, Rio, Greece.

(2) Anonymous, France.

Complete Peer review History: http://www.sciencedomain.org/review-history.php?iid=947\&id=12\&aid=8415

Original Research Article

Received $22^{\text {nd }}$ January 2015

Accepted $6^{\text {th }}$ March 2015

Published $12^{\text {th }}$ March 2015

\section{ABSTRACT}

Introduction: The ratio of male to female live birth is defined as male births divided by total births $(\mathrm{M} / \mathrm{T})$ and is expected to approximate 0.515 . This study was carried out in order to ascertain whether M/T in Malta was in any way influenced by the World Cup.

Methods: Index months were months in which the World Cup was held (always in June), from 1958 to 2010 ( $n=14)$. Live births were analysed for January before the event to nine months after (the following March).

Results: This study analysed 297254 live births. The decline from June to February was highly significant $(p=0.001)$. A dip in $M / T$ was noted in the February after the World Cup and this significantly lower when compared to the previous January to January period $(p=0.001)$. M/T in these Februaries was also significantly lower than that in the other Februaries in the rest of the period studied $(p=0.0023)$.

Discussion: The majority of fans side with Italian or English national teams for old colonial political reasons. Stress leading up to and following the World Cup may have reduced $\mathrm{M} / \mathrm{T}$ in Malta, with a rapid recovery when the effect passed.

Keywords: Malta; birth rate/*trends; sex ratio; soccer; infant, newborn; politics.

${ }^{*}$ Corresponding author: Email: victor.e.grech@gov.mt; 


\section{INTRODUCTION}

The proportion of male births is defined as male births divided by total births $(M / T)$ and is expected to approximate 0.515 , with a slight excess of males [1].

The factors that influence $\mathrm{M} / \mathrm{T}$ are legion but in summary, stressors and toxins tend to reduce this ratio $[1,2,3]$. This is because in the setting of unfavourable circumstances, pregnant women tend to spontaneously abort, losing male pregnancies at a greater rate than female pregnancies [1,2]. This accords with the TriversWillard hypothesis which proposes that female mammals have evolved the ability to influence $\mathrm{M} / \mathrm{T}$ so as to favour the propagation of their genes under conditions of stress [4].

The hypothesis proposes that since frail male offspring are unlikely to successfully compete for mating privileges with stronger males, they are lost, allowing the mother to become pregnant with a robust male or a female. A female offspring is not only hardier and likelier to survive, but also likelier to reproduce, passing on maternal genes. However, under favourable circumstances, robust male offspring have greater reproductive potential than female offspring who are limited by a gestational period. Hence, the maternal ability to influence $\mathrm{M} / \mathrm{T}$ confers an evolutionary advantage [4].

Of relevance to this study is the U-shaped regression on cycle day of insemination, with female conceptions resulting more often from conceptions around ovulation and male conceptions occurring more frequently at the beginning and end of the menstrual cycle $[5,6,7]$ Thus, increases in coital rates may skew $M / T$ in favour of male births since the chances of conception earlier in the menstrual cycle are increased $[8,9]$.

Soccer may have biological effects. For example, World Cup matches have been shown to be associated with an increased risk of admission with myocardial infarction [10].

It has also been shown that football may influence $M / T$. $M / T$ is significantly increased in Soccer (FIFA) World Cup years in 1978 and in 1994 for the winning countries, Argentina and Brazil respectively. Furthermore, Mexico hosted the event twice in 1970 and 1986, and this was associated with a significant decline in $\mathrm{M} / \mathrm{T}$ [11].
Malta is a small central Mediterranean island with a total population of just under half a million [12]. It is a developed country with low infant mortality and long life expectancy [13]. Soccer is followed obsessively in Malta and foreign games and leagues are preferred to local ones [14].

This study was carried out in order to ascertain whether $\mathrm{M} / \mathrm{T}$ was in any way influenced by upcoming World Cups or following such events.

\section{METHODS}

Monthly male and female births were obtained from official Malta Government publications dating back to $1958[12,15]$.

Index months were months in which the World Cup was held, from 1958 to 2010, in four year intervals $(n=14)$. For each World Cup month (which is always June), live births were summated for all events, ranging from the previous January to the following March (9-10 months later). Visual inspection of the data showed a clear dip in M/F in February, 8-9 months after the World Cup. The Februaries following the World Cup were therefore compared with the other Februaries in the dataset (1958-2013).

A seasonal/cyclic effect was not taken into consideration as it has been shown that $M / T$ does not exhibit any seasonal variation in Malta [16].

Excel was used for data entry, overall analysis and charting. The quadratic equations of Fleiss were used for exact calculation of $95 \%$ confidence intervals for ratios [17]. Chi tests and chi tests for trend were used for trend testing of male and female births using the Bio-Med-Stat Excel add-in for contingency tables [18]. A p value $\leq 0.05$ was taken to represent a statistically significant result.

The null hypothesis was that World Cup did not influence $\mathrm{M} / \mathrm{T}$ in Malta.

\section{RESULTS}

This study analysed 297254 live births over the period studied (1958-2013), consisting of 153652 males and 143602 females (M/T $0.5169,95 \% \mathrm{Cl}$ 0.5151-0.5187).

The decline from June to February was highly significant (chi=10.0, $p=0.001-$ Fig. 1). The dip in 
$\mathrm{M} / \mathrm{T}$ in the February after the World Cup was significantly lower when compared to the previous January to January period ( $p=0.0018$ Table 1). $\mathrm{M} / \mathrm{T}$ in these Februaries was also significantly lower than that in the other Februaries in the rest of the period studied $(p=0.0023-$ Table 1).

\section{DISCUSSION}

The World Cup has been shown to increase M/T in certain winning Latino countries and decrease $\mathrm{M} / \mathrm{T}$ in certain hosting Latino countries, and this was attributed to the passion with which these countries regard this sport. It was postpulated that higher coital rates associated with exuberance in the former may have skewed $M / T$ toward males, while stress in the latter may have skewed M/T toward females [11].

Politics has also been shown to influence $M / T$. For example, three acts of legislation enacted by the United States in order to facilitate migration from Communist Cuba to the United States were temporally associated with a fall in $M / T$ in the same or the following years, resulting in three significant one-year dips in this ratio over the period 1960-96 [19]. Moreover, the effect not only of conflict, but also the ratification of agreements between warring countries has also been shown to potentially have influenced $M / T$ in three countries in the Middle East [20].

It is possible that the observed $M / T$ shifts in relation to the World Cup may also have had a political stimulus. Indeed the Maltese obsession with soccer has been attributed to historical political influences [14].

Malta gained independence from the United Kingdom in 1964. This was only achieved after an attempt by the Labour Party for Malta to formally integrate with Britain broke down. Furthermore, this had been preceded by the Nationalist Party's leaning toward Italian irredentism [21].

Table 1. Comparison of M/T for Februaries after the world cup vs the previous January to January period and all other Februaries

\begin{tabular}{llll}
\hline & \multicolumn{2}{c}{ For world cup years } & For all period: 1958-2013 \\
\cline { 2 - 4 } & February after & January to January & All other Februaries \\
\hline Male & 2904 & 45715 & 8908 \\
Female & 2928 & 42357 & 8188 \\
Total & 5832 & 88072 & 17096 \\
Upper Cl & 0.5109 & 0.5224 & 0.5286 \\
$\mathrm{M} / \mathrm{T}$ & 0.4979 & 0.5191 & 0.5211 \\
Lower Cl & 0.4850 & 0.5158 & 0.5135 \\
\hline & Feb after vs. & January to January & All other Februaries \\
\hline Statistical & chi & 9.8 & 9.3 \\
analysis & $\mathrm{p}$ & 0.0018 & 0.0023 \\
\hline
\end{tabular}

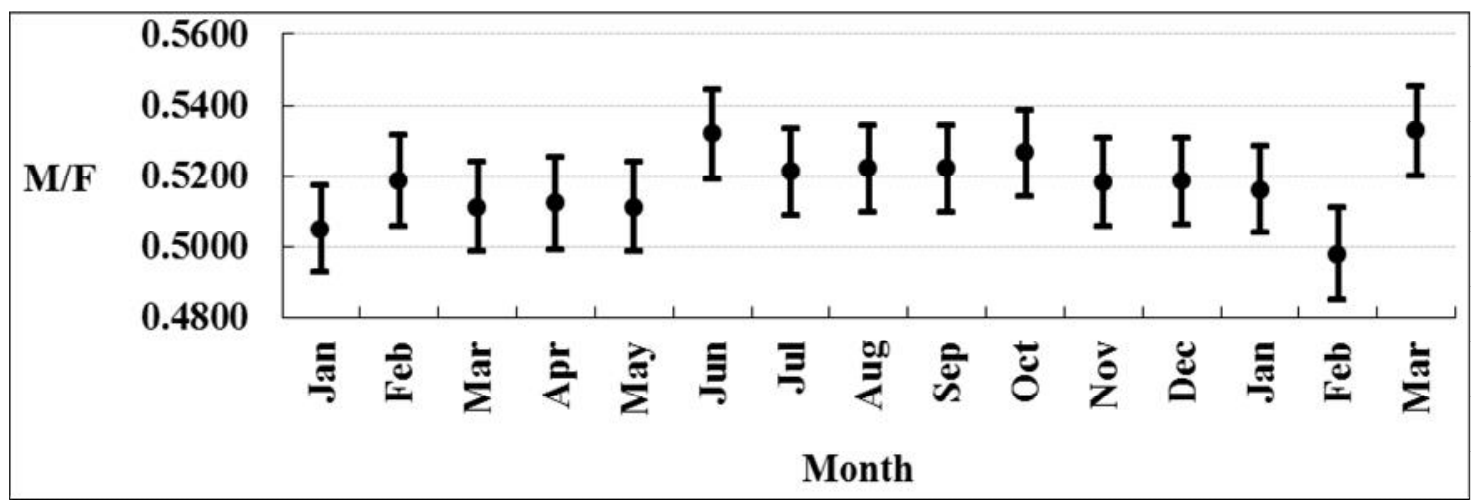

Fig. 1. Summation of $M / T$ for world cup years and the three months after 
Since 1966, the political situation has firmed into a two party system, Labour and Nationalist (Conservative), with overall relatively small but absolute majorities deciding election results [13]. Parliamentary elections have always been hotly contested, highly divisive and stressful, with voter turnout approaching $100 \%$. M/T in Malta has also been shown to be influenced by the local parliamentary elections, dropping in association with elections, and this has been attributed to the stress engendered by these events [22]. Party support is usually according to familial political leanings [21] resulting in a politically riven society to this very day.

It has further been argued that the Maltese political polarisation (which is purely ideological) has resulted in political parties almost taking the role of ethnie, to the extent that some scholars refer to two Maltese nations, riven by radically different ideas about the Maltese past, present and future, despite their fundamentally identical nationality and language [23].

It is therefore not surprising that the local proclivity toward being Anglophile or Italianate has led to bipartisanship even in soccer, with fans siding principally with Italian or English regional and national football teams [21]. Even in this context, fan leanings are usually on familial lines, and fan support for these teams far outstrips support to the local team [24,25].

It is perhaps because of this that with many local aficionados, soccer has become a literal obsession, with fans setting up special satellite dishes and waking up in the middle of the night to watch games on the other side of the globe [14]. In particular, Italian and English league games are avidly followed and fans commonly display an extraordinary knowledge of "their" team's historical successes, tactics and player selections [14].

The small local population is naturally unable to field an impressive team but it has been mooted that it is not only the team's serial ineptitude but also the schizophrenic local identity politics that pushes local fans to avidly support foreign teams [21].

Soccer is a passion for many Latino countries such as Italy and South American, [9] and fans arguably experience some degree of stress during matches. The reduction witnessed in this study following the World Cup is striking, with the 8-9 month dip actually inverting $\mathrm{M} / \mathrm{T}$ (less males born than females) as compared to the usual situation wherein Malta, like other Mediterranean countries, has a rather higher $\mathrm{M} / \mathrm{T}$ than the anticipated 0.515 [26]. These findings are not explained by seasonal variations as a more recent Maltese study has failed to show significant seasonal variation [27] and a comparison of $\mathrm{M} / \mathrm{T}$ of Februaries following the World Cup showed that the aggregate $\mathrm{M} / \mathrm{T}$ for these Februaries was significantly lower than the other Februaries in the dataset.

It has also been shown that $\mathrm{M} / \mathrm{T}$ is dependent on coital frequency, with higher rates raising $M / F$ due to higher occurrences of fertilisation at the beginning and end of the menstrual cycle. It has been shown that this increase $M / T$, while conversely, lower coital rates decrease $\mathrm{M} / \mathrm{T}$. Thus, lower coital rates may also have contributed to the decline in $\mathrm{M} / \mathrm{T}[5,6]$.

\section{CONCLUSION}

Stress leading up to and following the World Cup may have reduced $\mathrm{M} / \mathrm{T}$ in Malta, with a rapid recovery when the effect was past.

\section{CONSENT}

It is not applicable.

\section{ETHICAL APPROVAL}

It is not applicable.

\section{COMPETING INTERESTS}

Author has declared that no competing interests exist.

\section{REFERENCES}

1. James $\mathrm{WH}$. The human sex ratio. Part 1: $\mathrm{A}$ review of the literature. Hum Biol. 1987;59:721-52.

2. James WH. The human sex ratio. Part 2: $\mathrm{A}$ hypothesis and a program of research. Hum Biol. 1987;59:873-900.

3. Grech V, Mamo J. The male to female ratio at birth. Xjenza. 2014;2:81-90.

4. Trivers RL, Willard DE. Natural selection of parental ability to vary the sex ratio of offspring. Science. 1973;179:90-2.

5. Guerrero R. Association of the type and time of insemination within the menstrual cycle with the human sex ratio at birth. $\mathrm{N}$ Engl J Med. 1974;291:1056-9. 
6. Harlap S. Gender of infants conceived on different days of the menstrual cycle. $\mathrm{N}$ Engl J Med. 1979;300:1445-8.

7. Gray $\mathrm{RH}$. Natural family planning and sex selection: Fact or fiction? Am J Obstet Gynecol. 1991;165:1982-4.

8. Moeller RG. Protecting Motherhood: Women and the Family in the Politics of Postwar West Germany. Berkeley: University of California Press; 1993

9. James WH. Time of fertilisation and sex of infants. Lancet. 1980;1:1124-6.

10. Carroll D, Ebrahim S, Tilling K, Macleod J, Smith GD. Admissions for myocardial infarction and World Cup football: Database survey. BMJ. 2002;325:1439-42.

11. Grech V. Soccer world cup influences sex ratio at birth. Eur J Sports Med. 2014;2:2129.

12. Central Office of Statistics. Demographic review for the Maltese Islands. Malta: Central Office of Statistics (Annual publications)

13. Agius $F$. Health and social inequities in Malta. Soc Sci Med. 1990;31:313-8.

14. Armstrong G, Mitchell JP. Oppositional cultures in Maltese Football. In: Armstrong G, Giulianotti R. Fear and loathing in world football. Oxford: Berg Publishers; 2001.

15. Department of Health. Health Reports. Malta: Department of Health (Weekly publications)

16. Grech V, Vella C, Vassallo-Agius $P$, Savona-Ventura C. Gender at birth and meteorological factors. Int J Risk Safety Med. 2001;13:221-224.

17. Fleiss JL. Statistical methods for rates and proportions. New York: John Wiley and Sons. 1981;14-15(2 ${ }^{\text {nd }}$ edition).
18. Slezák P. Microsoft Excel add-in for the statistical analysis of contingency tables. Int J Innovation Educ Res. 2014;2:90-100.

19. Grech V. The influence of migration on secular trends in sex ratios at birth in cuba in the past fifty years. West Indian Med J. 2014;63:6-10.

20. Grech V. The effect of warfare on the secular trends in sex ratios at birth in Israel, Egypt, and Kuwait over the past 60 years. Libyan J Med. 2014;9:23448.

21. Baldacchino G. A nationless state? Malta, national identity and the EU. West European Politics. 2002;25:191-206.

22. Grech V. The male: female ratio at birth is depressed by Maltese parliamentary elections and increased by other nonelectoral events. Int J Tropical Dis Health. 2014;4:1123-1131.

23. Serracino-Inglott $P$. Was Malta a nation in 1964? In: Mallia-Milanes V. The British Colonial Experience 1800-1964: The impact on Maltese Society. Malta: Mireva; 1988.

24. Mitchell JP. Ambivalent Europeans: Ritual, memory and the public sphere in Malta. London: Routledge; 2002.

25. Mitchell JP. Modernity and the Mediterranean. J Medit. Studies. 2002;12: 1-21.

26. Grech V, Vassallo-Agius $P$, SavonaVentura C. Declining male births with increasing geographical latitude in Europe. J. Epidemiol. Community Health. 2000;54: 244-246.

27. Grech V, Borg T. An analysis of seasonal variation and climatic influences on the male to female ratio of live births in Malta. Int J Tropical Dis Health. 2015;5:123-129.

(c) 2015 Grech; This is an Open Access article distributed under the terms of the Creative Commons Attribution License (http://creativecommons.org/licenses/by/4.0), which permits unrestricted use, distribution, and reproduction in any medium, provided the original work is properly cited.

Peer-review history:

The peer review history for this paper can be accessed here:

http://www.sciencedomain.org/review-history.php?iid=947\&id=12\&aid=8415 